\title{
THE QUESTION OF ACCOUNTABILITY: NEW FORMS OR A DEMOCRATIC DEFICIT
}

\author{
Idoko Peter ${ }^{1 *}$ \\ ${ }^{*}$ Consultancy Unit, Nassarawa State Polytechnic, Lafia, Nigeria.
}

\section{*Corresponding Author: -}

\begin{abstract}
: -
This research examined the question of accountability; new forms or a democratic deficit. The study examined specially examines the relationship between transparency and accountability, relationship between technocratic decision making and accountability and finally the relationship between proper coordination and accountability. The study is an exploratory study that used mainly secondary sources of information obtained from journals, text books and from the internet. The findings from the review shows that public accountability is important because it provides a democratic means to monitor and control government conduct, prevent the development of concentrations of power, and enhance the learning capacity and effectiveness of public administration. This is because rulers can be investigated and held to account for actions that transgress the law or result in personal enrichment or violate common mores. These tenets are lacking in our public institutions and in broader perspective the government. The study concludes that large changes in politics, especially for the citizens of the European Union, with the latest enlargement in which brought the union to 27 member states and a half a billion people has been recorded, raising questions on issues such as democracy and the people's options of accountability. It was recommended among others that it will be fair for all the operators to play the game of leadership according to the established rules and regulations to promote transparency. Also, the experts are to be given free hand to exercise their expertise to usher in accountability for the growth of the system. It was also recommended that it is advisable for all the operators to exhibit probity to eliminate fraudulent behavior.
\end{abstract}

Keywords: Accountability, Democratic, Government, Deficit 


\section{INTRODUCTION}

In ethics and governance, accountability is answerability, blameworthiness, liability, and the expectation of accountgiving. As an aspect of governance, it has been central to discussions related to problems in the public sector, nonprofit and private (corporate) and individual contexts. In leadership roles, accountability is the acknowledgment and assumption of responsibility for actions, products, decisions, and policies including the administration, governance, and implementation within the scope of the role or employment position and encompassing the obligation to report, explain and be answerable for resulting consequences.

In governance, accountability has expanded beyond the basic definition of "being called to account for one's actions". It is frequently described as an account-giving relationship between individuals, e.g. "A is accountable to B when A is obliged to inform B about A's (past or future) actions and decisions, to justify them, and to suffer punishment in the case of eventual misconduct". Accountability cannot exist without proper accounting practices; in other words, an absence of accounting means an absence of accountability.

Accountability is a contestable concept par excellence. Anyone studying accountability will soon discover that it can mean many different things to many different people (Mulgan, 2000, 555; Behn 2001, 3-6;

Dubnick, 2002; Pollitt, 2003, 89). Conveying an image of transparency and trustworthiness it is evocative and used in political discourse and policy documents. Moreover 'accountability' often serves as a conceptual umbrella covering various other often highly contested concepts. For example, the European Commission (2001, 2003) uses 'accountability' rather loosely. It serves not only as a synonym for 'clarity', 'transparency', and 'responsibility', but it is also equated with much broader concepts such as 'involvement, 'deliberation', and 'participation'. One of the reasons for this conceptual ambiguity and multiplicity is the fact that 'accountability' is an Anglo-Norman concept (Dubnick, 2002), which has no semantic equivalents on the European continent.

In the American academic and political discourse, accountability is used predominantly as a normative concept, as a set of standards for the evaluation of the behaviour of public actors. Accountability or, more precisely, 'being accountable', is seen as a virtue, as a positive quality of organizations or officials. Hence, accountability studies often focus on normative issues, on the assessment of the actual and active behaviour of public agents (Dubnick, 2002; Koppell, 2005). Accountability in this very broad sense is basically an evaluative, not an analytical concept. It is used to positively qualify a state of affairs or the performance of an actor. It comes close to 'responsiveness' and 'a sense of responsibility', a willingness to act in a transparent, fair, and equitable way. Accountability in this broad sense is an essentially contested and contestable concept, because there is no general consensus about the standards for accountable behaviour, and they differ from role to role, time to time, place to place, and from speaker to speaker. In British, Australian, and continental European scholarly debates, accountability often is used in a much more narrow, descriptive sense. Accountability is seen as a social mechanism, as an institutional relation or arrangement in which an actor can be held to account by a forum (Day and Klein, 1987; Mulgan, 2003; Meijer and Schillemans, 2007). Here the locus of accountability studies is not the behaviour of public agents, but the way in which these institutional arrangements operate. And the focus of account-ability studies is not whether the agents have acted in an accountable way, but whether they are or can be held accountable ex post facto by accountability forums. Both concepts, the broad one, in which accountability is seen as a personal or organizational virtue, and the narrow one, in which accountability is defined as a social mechanism, are very useful for the study of, and the debate about, democratic governance beyond the state. However, they should be distinguished, as they address different sort of issues and imply very different sort of standards and analytical dimensions. What are we to make of these new, more horizontal forms of accountability? Can they help to limit accountability deficits in European governance? This means that we move from an empirical to an evaluative analysis. In order to get some grip on these complex normative questions, I make yet one more distinction. Accountability may serve various purposes with regard to public governance, and each of these purposes can function as a perspective for the evaluation of accountability arrangements and to identify potential deficits. In the academic literature and in policy publications three perspectives recur, albeit implicitly, time and again. Public accountability is important to provide a democratic means to monitor and control government conduct, it is important for preventing the development of concentrations of power, and, finally, to enhance the learning capacity and effectiveness of public administration.

\section{Statement of Problem}

Public accountability is important because it provides a democratic means to: monitor and control government conduct, prevent the development of concentrations of power, and enhance the learning capacity and effectiveness of public administration. As fiendishly complex as it is, political accountability has to be institutionalized if it is to work effectively, i.e., it has to be embedded in a stable, mutually understood and pre- established set of rules. Some of these may be formalized in a constitution, in basic legal codes or in sworn oaths, but political accountability is not the same as legal, financial or ethical accountability. Rulers can be investigated and held to account for actions that did not transgress the law or result in personal enrichment or violate common mores. These tenets are lacking in our public institutions and in broader perspective the government.

In a democracy, the principle of accountability holds that government officials whether elected or appointed by those who have been elected are responsible to the citizenry for their decisions and actions. Without accountability and transparency, democracy is impossible. It should be noted that political accountability is not only partially impossible in our clime as different obstacles impedes its actualization. This is largely because citizens in a democracy or their representatives do not normally desire to "throw the rascals out." This form of government does offer regular and periodic occasions when this can be done peacefully, although in parliamentary systems the opportunities are more 
dispersed, irregular, and potentially costly. Moreover, regardless of the executive-legislative format, rulers have a considerable array of mechanisms to defend themselves against such an eventuality.

It is in the light of the above that this study examines the relationship between transparency and accountability, relationship between technocratic decision making and accountability and finally the relationship between proper coordination and accountability.

\section{Literature Review \\ Theoretical Framework Accountability theory}

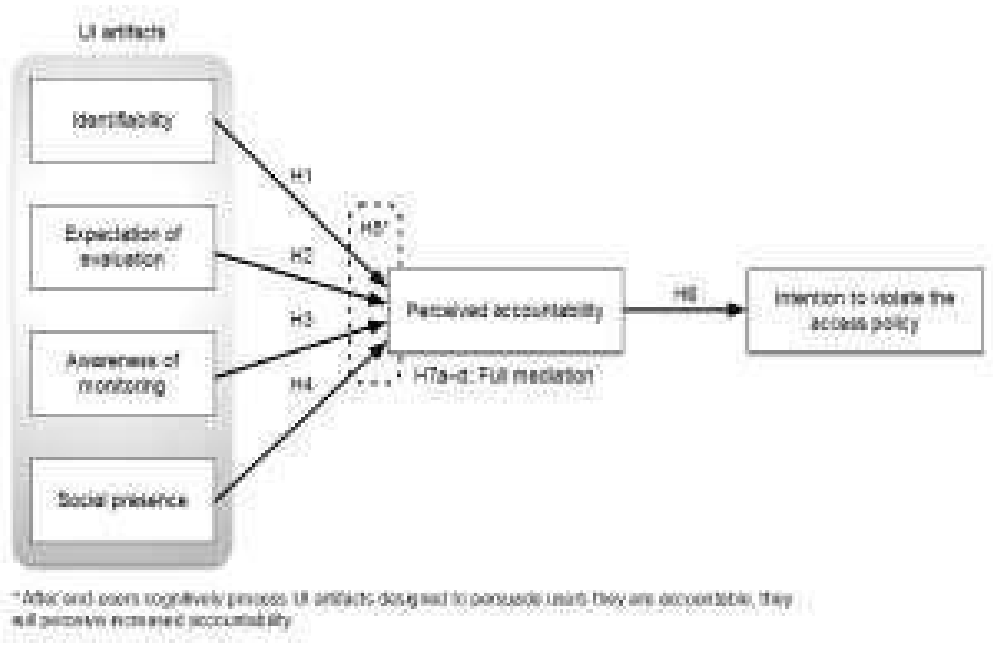

As explained by Vance, Lowry and Eggett (2015), accountability theory explains how the perceived need to justify one's behaviors to another party causes one to consider and feel accountable for the process by which decisions and judgments have been reached. In turn, this perceived need to account for a decision-making process and outcome increases the likelihood that one will think deeply and systematically about one's procedural behaviors. This theory was originally developed by Tetlock, Lerner, and colleagues and has been effectively applied in organizational research.

Importantly, as explained carefully by Vance, Lowry, and Eggett (2013), a useful way to understand accountability is to distinguish between its two most prevalent uses: (1) as a virtue and (2) as a mechanism. As a virtue, accountability is seen as a quality in which a person displays a willingness to accept responsibility, a desirable trait in public officials, government agencies, or firms; hence, in this use, accountability is a positive feature of an entity. As a mechanism, accountability is seen as a process in which a person has a potential obligation to explain his or her actions to another party who has the right to pass judgment on the actions as well as to subject the person to potential consequences for his or her actions. Accountability theory focuses on the process of accountability.

Accountability theory proposes several mechanisms that increase accountability perceptions. For example, "even the simplest accountability manipulation necessarily implicates several empirically distinguishable sub manipulations" (Lerner and Tetlock 1999, p. 255), including the presence of another person, identifiability, and expectation of evaluation. Recent research has shown that IT design artifacts of systems can manipulate the four core components of accountability theory and thus improve employees' felt accountability toward organizational system security without disruptive interventions or training (Vance et al. 2013; 2015): (1) identifiability, (2) expectation of evaluation, (3) awareness of monitoring, and (4) social presence. Identifiability is a person's "knowledge that his outputs could be linked to him" and thus reveal his/her true identity (Williams, Harkins and Latane 1981, p. 309). Expectation of evaluation is the belief that one's "performance will be assessed by another [party] according to some normative ground rules and with some implied consequences" (Lerner and Tetlock 1999, p. 255). Awareness of monitoring is a user's state of active cognition that his/her system-related work is monitored (Vance, Lowry, and Eggett 2015). Social presence is the awareness of other users in the system (Vance, Lowry, and Eggett 2015).

\section{Conceptual Framework}

\section{Accountability in Public Sector}

The public sector in Nigeria is irrefutably beset with gross incompetence and ineffective management. Perplexing difficulties endure in the Nigerian public sector in spite of a number of reform programmes that have been designed to enhance efficient and effective service delivery for almost two decades. The fact that public service has failed dismally to achieve its laudable objectives is the reason for the vote of no confidence passed on its administrators by majority of the Nigerian populace. The article examines the dilemma of accountability and good governance in Nigeria and demonstrates that the critical point in achieving meaningful developments in the country intrinsically lay with improved service delivery in the public sector. The basic reason why the public service has become the scorn of the people is because for too long, both the government and public servants have paid lip service to the crucial issue of effective and efficient service delivery.

The notion of accountability is an amorphous concept that is difficult to define in precise terms. This according to Blind (2011:8) partly arises from its dualistic nature as a concept. According to him, accountability is abstract and value- 
ridden because it is associated with, inter alia, the notions of responsibility, integrity, democracy, fairness and justice. As noted by Roger and Mac-Williams (2001:46), accountability is said to have Roman origin denoting "To stand forth and be counted." Accountability means you have a hand in all things you have created, promoted, or allowed. It refers to the ability to furnish satisfactory analyses and explanation of one's actions in the process of discharging one's responsibilities at all levels, whether technical, administrative, political, financial, or otherwise (Ola \& Effiong, 1999:44). In his own view, Okechukwu (2007:32) sees accountability as the execution of one's duties and conducts in public offices; it has been noted to constitute a powerful tool in the struggle for human right implementation. It makes it possible for people and organizations to identify important actors and hold them accountable for their actions. Accountability can also be seen as a relationship of power, where the less powerful 'principal' has the right to ask the more powerful 'agent' to explain his/her actions, and has the capacity to impose penalties for poor performance According to Stewart (Hondeghorn, 1998:7), accountability rests both on giving an account and on being held to account. Ackerman (2005:18) stresses two variants of accountability: accountability as "honesty" and accountability as "performance." On an individual level, the first variant is associated with the rule-following bureaucrats who restrain from the nonprocedural, and the second variant, with the pro-active public decision-makers who are expected to perform efficiently and effectively. Ackerman indicates that the first "honesty" version is "process-oriented"

And "negative" accountability because the public servants are evaluated through time, and based on the extent to which they abide by the standard operating principles. As for the second, "performance," understanding of accountability, the association is with "results- driven" and "positive" accountability insofar as accountability is seen as the ability to produce effective policy outcomes, which are evaluated at project endings. Another scholar who has taken a step towards a continuous graded view of accountability is Joshi (2010:15). He focuses more specifically on accountability in the area of public service delivery which is the focus of this article. He favours the "short route" of accountability; i.e., the more visible and direct linkages between users (citizens) and providers (street- level bureaucrats) as opposed to the "long route," where elected politicians and public officials are accountable to the service- recipient citizens through the providers. In this more tightly circumscribed milieu, the continuous process of accountability is conceived to include the following stages: setting standards, getting information about actions, making judgments about appropriateness, and sanctioning unsatisfactory performance. According to Joshi (2010:22), there is high ambiguity in the literature about which stages are essential for a particular accountability initiative to be robust.

Accountability is a central piece of good governance. It enables the sharing of power (concept of checks and balance) and the public control over the use of public resources. It contributes to reducing the risk of power abuse and corruptive practices, which in turn is essential to ensure the fulfillment of peoples' basic human rights. Well-functioning accountability relations contribute to build trust in State institutions and processes of managing public affairs. This can be particularly important in situations of conflict. Accountability describes the relation between state institutions and people, private sector affected by their decisions. It is about the obligation of state institutions, or any other authority with assigned public duties to inform the public, to explain, justify their decisions and actions (information, answerability). And it is about the right and responsibility of the citizens to access information, get explanations, to check, and to pass judgment on the conduct of those with public responsibilities.

This requires a political system, which ideally is providing space for citizen participation and consultation, an independent, pluralistic media, effective parliaments and independent oversight bodies. And it needs mechanisms for sanctioning misbehaviour (enforceability), e.g. with an independent, impartial and accessible justice system. Accountability matters from a democratic perspective as it makes it possible to call to account in a democratic fashion those holding public office (March and Olsen, 1995, 141-181; Mulgan, 2003). This approach reaches back to the tenets of Rousseau and Weber and has been theoretically defined using the principal-agent model. Hence, public accountability is an essential condition for the democratic process providing voters and their representatives with the information needed for judging the propriety and effectiveness of the conduct of the government (Przeworski et al., 1999). One major accountability deficit from this perspective is the political accountability of the Council at the European level. Neither the Council itself, nor its individual members are accountable to any political forum at the European level (Van Gerven, 2005, 85, 91). Parliaments can try to hold their individual representatives to account at the national level - which may turn out to be increasingly difficult with the rise of qualified majority voting — but there is no collective political, let alone democratic, accountability of the Council as a whole.

Generally, however, voters do not have any direct way of holding elected representatives to account during the term for which they have been elected. Additionally, some officials and legislators may be appointed rather than elected. Constitution, or statute, can empower a legislative body to hold their own members, the government, and government bodies to account. This can be through holding an internal or independent inquiry. Inquiries are usually held in response to an allegation of misconduct or corruption. The powers, procedures and sanctions vary from country to country. The legislature may have the power to impeach the individual, remove them, or suspend them from office for a period of time. The accused person might also decide to resign before trial. Impeachment in the United States has been used both for elected representatives and other civil offices, such as district court judges.

In parliamentary systems, the government relies on the support or parliament, which gives parliament power to hold the government to account. For example, some parliaments can pass a vote of no confidence in the government. Belsky et al. point out, whereas, under more democratic governance accountability is built into the institution of the state by a 
habit of regular elections, accountability in autocratic regimes relies on a selectorate; a group that legitimizes or delegitimizes the autocrats powers according to selectorate theory. The primary mechanism at a selectorate's disposal is deposition, which is a form of exit. Beyond those institutions can act as credible restraints on autocracy as well. Researchers at the Overseas Development Institute found that empowering citizens in developing countries to be able to hold their domestic governments to account was incredibly complex in practice.

\section{Relationship between Technocratic Decision Making and Accountability}

Within an organization, the principles and practices of ethical accountability aim to improve both the internal standard of individual and group conduct as well as external factors, such as sustainable economic and ecologic strategies. Also, ethical accountability plays a progressively important role in academic fields, such as laboratory experiments and field research. Debates around the practice of ethical accountability on the part of researchers in the social field whether professional or others - have been thoroughly explored by Norma Romm in her work on Accountability in Social Research, including her book on New Racism: Revisiting Researcher Accountabilities, reviewed by Carole Truman in the journal Sociological Research Online. Here it is suggested that researcher accountability implies that researchers are cognizant of, and take some responsibility for, the potential impact of their ways of doing research - and of writing it up - on the social fields of which the research is part.

The main concern underlying this constitutional perspective is that of preventing corruption and the abuse of state powers. The remedy is the organization of institutional countervailing powers. Other public institutions, such as an independent judicial power, are put in place next to the voter, parliament, and political officials, and are given the power to request that account be rendered over particular aspects. From this constitutional perspective, the picture is far brighter. The EU is held together by an elaborate, multi-level system of legal, financial, and administrative checks and balances. It has been a constant point of concern whether the Commission itself, as the major executive power within the EU, is not prone to corruption or other forms of administrative deviance. Much effort has gone into holding the European executive at bay. This has not been without success. Magnette $(2003,51)$ argues that the European Commission 'is one of the most controlled executives in the world. Situated between the Council and the Parliament, subject to the jurisdiction of the ECJ, watched over by the Ombudsman, the Court of Auditors and a series of ad hoc bodies, it is surrounded by mechanisms of control'. However, it remains an empirical question whether all of these formal mechanisms are effective in practice to hold the Commission at bay. Accordingly, the major source of concern would, again, be some of the newly established agencies, because they involve classic state monopolies: monetary powers in case of the ECB, policing powers in case of Europol and military powers in case of the EDA.

These are the sort of executive functions that you want to have checked and balanced. Another possible locus of unfettered powers may lie again in the substantial role of experts in EU policymaking, particularly in the comitology procedures. Thirdly, from a cybernetic perspective on accountability, the purpose of accountability lies also in maintaining and strengthening the learning capacity of the government (Aucoin and Heintzman, 2000, 52-54). Accountability is not only useful as a check, but it also leads to prevention. Public accountability offers a regular mechanism to confront officials and administrators with information about their own functioning and forces them to reflect on the successes and failures of their past policies (Luhmann, 1966). The second report of the Committee of Independent Experts, that was established to investigate allegations of fraud and corruption by the Santer Commission, fits within this perspective. In its second report, the committee formulated no less than 90 recommendations concerning the management and control of European governance, many of which eventually found their way into reform proposals (Van Gerven, 2005, 82).

Social forms of accountability may be of help too in creating checks and balances. Monitoring of the EU executive by civil society organizations such as State watch or the European Civil Liberties Network, or public expenditure tracking by investigative journalists, may become increasingly important at the EU level to provide informal controls on the abuse of powers. The possibility of independent external evaluations of (some) European agencies is a very interesting innovation that rewards attention in the coming years. Both administrative and social forms of accountability also can be quite valuable from the learning perspective. Citizen monitoring and evaluation of public service delivery by independent agencies has been helpful at the national level to provide policymakers with feedback about the legitimacy and the effects of governance. It may well be that the new executive European agencies turn out to be important breeding grounds for new forms of accountability in this respect too.

While the ratification of the constitution remains highly uncertain after the negative referenda in France and The Netherlands, gaping accountability deficits may continue to exist and even grow, compromising the legitimacy of the European polity (Bergman and Damgaard,2000; Curtin, 2004). Given the widespread concern about the "European democratic deficit", it seems remarkable that through most of the history of European integration that was not an issue at all. For decades, political actors and publics were content to assume the legitimacy of European institutions and policy processes even though these did not resemble the patterns of democratic governments at the national level.

By contrast, the present debate often assumes that a lack of institutional isomorphism with the constitutions of democratic nation states must imply a lack of European legitimacy. Ignoring the possibilities, and the importance, of functional equivalence, such debates tend to generate either undue pessimism or unrealistic hopes an counterproductive recommendations for institutional reform. In order to avoid both of these pitfalls, I will begin with an abstract discussion of the prerequisites of legitimate governance and then consider the legitimacy and limited problem-solving effectiveness of present EU governing modes. Next, I will then try to show that currently discussed institutional reforms that would increase problem-solving effectiveness will encounter severe legitimacy problems, and I will conclude by suggesting options that might evade this dilemma. 
However, at the same time as output-oriented legitimacy arguments emphasize the dangers following from the abuse of governing powers, they also presuppose a need for effective government with a capacity for achieving common purposes and dealing with common problems that are beyond the reach of individuals and families acting on their own, through market exchanges, or through uncoerced cooperation in civil society. Within the output-oriented perspective, there is thus an obvious and problematic tension between institutional arrangements designed to prevent wrongdoing by governors and exploitation by special interests on the one hand, and institutional arrangements facilitating the vigorous pursuit of the common interest and effective problem-solving on the other hand. As the functions of governments have vastly increased in comparison to those that were presupposed by eighteenth-century normative theories, this tension has also gained in practical importance, While specific institutional forms vary widely among constitutional democracies, it is generally true that more safeguards against the abuse of governmental power imply an increase in the number of veto positions, and that more veto players imply a lower capacity for effective action (Tsebelis 2002). Depending on differences in their historical experience and societal and political cohesion, the constitutions of democratic politics will be closer to one or the other pole. Thus, Westminster-type regimes in the UK and, until recently, in New Zealand minimize the institutional obstacles against government action which, if employed wisely, may facilitate effective policy responses to new challenges, whereas an extreme form of multiple-veto constitution has rendered policy reform very difficult in Germany (Scharpf and Schmidt, 2000).

In short, democratic constitutions vary not only in the relative emphasis they place on structures and procedures supporting input- oriented and output-oriented legitimating arguments, but within the context of output- oriented considerations, they also vary in the relative emphasis placed on power- constraining versus action-enabling features. In any case, however, all of these normative dimensions are considered relevant for democratic legitimacy at the national level; and even if trade-offs are acknowledged, one could not argue that performance in one dimension would fully substitute for deficits in another. As the Economist stressed, the weak foundations of popular accountability may prove the Union's Achilles heel. There are two related senses in which an applied evaluation of the democratic legitimacy of an international institution rest on empirical judgments. First, each of the four ideal theories discussed above rests on explicit empirical judgments about politics and society. Libertarians stress the tendency for regulators to act for narrow and arbitrary rather than for publicly justifiable reasons, the unbounded power of international institutions, and the socialist bias of policy- making. Pluralists stress the lack of democratic constraints on policy-making in international organizations. Social democrats stress the neo- liberal bias in international policy-making and the existence of pressures triggering a 'race to the bottom'. Deliberative democrats argue that international institutions help create a passive, unsatisfied public. Each of these empirical claims can and should be subjected to rigorous testing before we accept the normative conclusions that follow. Second, each of the four ideal theories above remains a normative ideal of democracy. Each invites a comparison between inter-national institutions and an ideal form of perfectly participatory, egalitarian, deliberative politics. Such ideals are frankly utopian.

This empirical translation from the ideal to real is likely to be complex and non-linear, such that the ideal policy in a 'best' world of perfect citizens (e.g., participation) often runs directly counter to the 'good' policy in a second-best world of concrete politics (e.g., delegation). While, for example, we can say with considerable confidence that an entirely undemocratic system - that is, a system that offers no meaningful participation in decision- making at any level -is democratically illegitimate, the same proposition does not hold on the margin. In other words, there is no reason to believe that a marginal increase in direct participation by the average citizen in majoritarian or consensus decisionmaking, as opposed to delegation and insulation of policy-makers, promotes outcomes that can be more easily justified in terms of normative and positive democratic theory.

One way to calibrate the standards used to assess real-world democratic systems is to employ comparative social scientific analysis. In order to assess the extent to which a given insulation or delegation of power in an international organization is democratically legitimate, we may ask whether a similar institutional adaptation is widely accepted in existing democratic systems. Such national systems, at least among the advanced industrial democracies, can be presumed to be democratically legitimate in a broad sense, and thus the practices widely employed among such countries provide a meaningful baseline for assessing the democratic legitimacy of international organizations.

Widespread concern about the democratic deficit of European integration is a fairly recent phenomenon. According to the view prevailing before the Single European Act (SEA) and the Maastricht Treaty, the integration process derives its legitimation from the democratic character of the Member States. National parliaments ratify the Treaties; democratically accountable heads of state or government, meeting in the European Council, set strategic priorities; the Council of Ministers, composed of people who are normally elected members of the national executives, must approve Commission's proposals before they become European law. Thus, the entire process is guided and controlled by sovereign democratic states. This scheme of indirect legitimation, even if it was never free from ambiguities and doubtful assumptions, was considered to be sufficient as long as the Community dealt mainly with such matters as tariff reductions and agricultural quotas. In fact, the scheme makes perfect sense in an inter governmentalist perspective.

A fully-fledged social policy at European level would not only prevent such negative developments; it would also increase the legitimacy of the EC just as, in the past, social policies proved to be an essential source of democratic legitimation for the nation state. Historically, social security, health and welfare services, education, housing policy, represented powerful symbols of national solidarity, providing needed legitimation to the process of integration of the national market. A comprehensive European social policy, it is argued, could do the same for European economic integration.

Actually, it is more likely that the result would be exactly the opposite. To begin with, it should be noted that the very 
modest role of traditional social policy in the process of European integration is largely due to the reluctance of the Member States, including the national parliaments, to surrender control of such a politically sensitive area of public policy, and to transfer the necessary competences and resources to the Community. This reluctance is clearly expressed in the Treaty of Rome. The enumeration of matters relating to the social field in Article 118, and the limited role given to the Commission in Title III, Part Three of the Treaty, indicate that the social policy domain, with a few exceptions such as the social security regime for migrant workers, was originally considered to be beyond the competence of Community institutions. Neither the Single Act nor the Maastricht and Amsterdam Treaties have provided true legislative competences in the social field. On the contrary, harmonization of national laws and regulations in areas such as health care and social security is explicitly excluded.

\section{Democratic Deficit in European Union}

A democratic deficit (or democracy deficit) occurs when ostensibly democratic organizations or institutions (particularly governments) fall short of fulfilling the principles of democracy in their practices or operation where representative and linked parliamentary integrity becomes widely discussed. The phrase democratic deficit is cited as first being used by the Young European Federalists in their Manifesto in 1977, which was drafted by Richard Corbett. The phrase was also used by David Marquand in 1979, referring to the then European Economic Community, the forerunner of the European Union.

The German Constitutional Court referred to a "structural democratic deficit" inherent in the construction of the European Union. It found that the decision-making processes in the EU remained largely those of an international organisation, which would ordinarily be based on the principle of the equality of states and that the principle of equality of states and the principle of equality of citizens cannot be reconciled in a Staatenverbund. In other words, in a supranational union or confederation (which is not a federal state) there is a problem of how to reconcile the principle of equality among nation states, which applies to international (intergovernmental) organisations, and the principle of equality among citizens, which applies within states. A 2014 report from the British Electoral Reform Society wrote that "[t]his unique institutional structure makes it difficult to apply the usual democratic standards without significant changes of emphasis. Certainly, the principles of representativeness, accountability and democratic engagement are vital, but the protection of the rights of minorities is perhaps especially important. The EU is a political regime that is, in one sense at least, entirely made up of minorities.

The problem of the 'democratic deficit' is whether these direct and indirect channels are effective in connecting the preferences of citizens to the outcome of EU decision making. During the early years of the Community the technocratic and diplomatic elite determined the direction of European development, much as they controlled bodies such as NATO, with the tacit approval of a permissive consensus among mass publics. The idea of permissive consensus' implies general support within public opinion, with passive approval which is widespread if shallowly rooted, and which may allow future government action (Key 1961: 32-35). But there was always concern that public opinion about the future of Europe was somewhat fragile. Given limited popular participation in, and identification with, the European Union, decisions might easily be made by elites that would neither reflect, nor be seen to reflect, popular wishes. The breakdown in this consensus first became evident in the early 1990s. The defeat of the proposal to adopt the Maastricht Treaty in the Danish referendum of 1992, and then the 'petit oui' in France, produced a realization that at least some governments might be significantly out of touch with their electorate (Franklin, van der Eijk \& Marsh 1995; Franklin, Marsh \& McLaren 1994). The backlash against Maastricht and the ratification crisis were attributed, at least in part, to a lack of public engagement and popular debate about integration (Baun 1996). The period from 199192 saw a sharp fall in public support towards the European Union, across the standard indicators in the EuroBarometer (Niedermayer \& Sinnott 1995: 58-59). This fall was not just confined to opinion polls, as it occasionally found expression in violent actions, such as opposition by intense minorities to farming and fisheries policies. Problems of EU legitimacy were further underlined by the June 1994 European elections, with record apathy in voter turnout, and gains for anti-Maastricht protest parties in France, Denmark and Spain (van der Eijk \& Franklin 1996).

In 1996 these strains to the system were exacerbated and dramatized by the economic difficulties of achieving the strict convergence criteria for European Monetary Union, resulting in severe cuts in the welfare state in France and Italy. This was compounded by the political problems of persuading the public to abandon the familiar German Mark, French Franc and Pound Sterling in their pockets for the unknown Euro. The problem of the democratic deficit, given these stresses, is not just marginal to the enterprise, but central to the European project.

For example, if domestic political systems often grant constitutional courts and central banks a certain measure of political independence, this is one reason to believe that a similar grant is legitimate.

\section{Conclusion}

From the foregoing, the preceding discussion of accountability have demonstrated that the concept has a very complex and "tricky" structure. For one thing, some of its positive properties may be incompatible with each other or, at the very least, involve complex tradeoffs. Democratic and accountable politicians very frequently have to take risks of this sort and follow courses of action that are not immediately popular, with the calculation that once the effects are experienced the citizenry will have learned to accept them. The inference to be drawn from this is that accountability relationship is one in which an individual, group or other entity makes demands on an agent to report on his or her activity, and has the 
ability to impose costs on the individual or the agent. The study shows that in the last decade, large changes in politics, especially for the citizens of the European Union, with the latest enlargement in which brought the union to 27 member states and a half a billion people has been recorded raising questions on issues such as democracy and the peoples options of accountability.

\section{Recommendation}

- It will be fair for all the operators to play the game according to the rules and regulations to promote transparency.

- The experts are to be given free hand to exercise their expertise to usher in accountability for the growth of the system

- It is necessary for proper coordination to take place so that the system will develop to enhance accountability

- It is advisable for all the operators to exhibit probity to eliminate fraudulent behavior.

\section{Reference}

[1].Arnull, A. and Wincott, D.(2003)Accountability and Legitimacy in the European Union, New York and Oxford: OUP.

[2].Aucoin, P. and Heintzman, R.(2000) 'The dialectics of accountability for performance in public management reform', International Review of Administrative Sciences66: 45-55.

[3].Abromeit, Heidrun 2002: Wozu braucht man Demokratie? Die postnationale Herausforderung der Demokratietheorie. Opladen: Leske + Budrich.

[4].Barbe, E.(2004) 'The evolution of CFSP institutions: where does democratic accountability stand?' The International Spectator2: 47-60.

[5].Barberis, P.(1998) 'The new public management and a new accountability', Public Administration, 76: 451-470.

[6].Behn, R.D. (2001)Rethinking Democratic Accountability, Washington, DC: Brookings Institution Press.

[7].Bergman, T. and Damgaard, E.(eds.) (2000)Delegation and Accountability in the European Union, London: Frank Cass.

[8].Bono, G.(2002) 'Democratic accountability of military and police co-operation within the EU', Working Paper Series. PCAF Workshop on Parliamentary Oversight of International Military Cooperation/Institution. Geneva: DCAF.

[9]. Bovens, M.(1998). The Quest for Responsibility: Accountability and Citizenship in Complex Organisations, Cambridge: Cambridge University Press.

[10]. Curtin, D.(2004)Mind the Gap: The Evolving EU Executive and the Constitution, Third Walter van Gerven Lecture, Leuven Groningen: Europa Law Publishing.

[11]. Curtin, D.(2006) 'Delegation to EU Non- majoritarian Agencies and Emerging Practices of Public Accountability', in

[12]. D. Gerardin, R. Munoz and N. Petit (eds.)Regulation Through Agencies in the EU: A New Paradigm of European Governance, London: Edward Elgar, pp.88-119.

[13]. Dunn, Delmer D. 1999: Mixing Elected and Nonelected Officials in Democratic Policy Making. Fundamentals of Accountability and Responsibility. In: Adam Przeworsky, Susan Stokes and Bernard Manin (eds.), Democracy, Accountability, and Representation. Cambridge: Cambridge University Press, 297-326.

[14]. Dubnick, M.J. (2002) 'Seeking salvation for accountability, paper presented at the 2002 Annual Meeting of the American Political Science Association, Boston.

[15]. Elster, Jon 1998: Introduction. In: Jon Elster (ed.), Deliberative Democracy.

[16]. Cambridge: Cambridge University Press, 1-18.

[17]. Fisher, E.(2004) 'The European Union in the age of accountability', Oxford Journal of LegalStudies24(1): 495515.

[18]. Van Gerven, W.(2005). The European Union: A Polity of States and People, Oxford and Portland, Oregon: Hart.

[19]. Harlow, C.(2002)Accountability in the European Union, Oxford: Oxford University Press.

[20]. Harlow, C.and Rawlings, R.(2006) 'Promoting accountability in multi- level governance: a network approach', European Governance papers No.C-06-02.

[21]. Koppell, J.G.S. (2005) 'Pathologies of accountability: ICANN and the challenge of "multiple accountabilities disorder', Public Administration Review65(1): 94-107.

[22]. Lord, C.(2004)A Democratic Audit of the European Union, Basingstoke: Palgrave/MacMillan.

[23]. Luhmann, N.(1966) Theorie der Verwaltungswissenschaft: Bestandsaufnahme und Entwurf, Koln- Berlin.

[24]. Magnette, P.(2003) 'Between parliamentary control and the rule of law: the political role of the Ombudsman in the European Union', Journal of European Public Policy, 10/5: 677-694.

[25]. Magnette, P., Lequesne, C., Jabko, N. and Costa, O. (2003). 'Conclusion: diffuse democracy in the European Union: the pathologies of delegation', Journal of European Public Policy, 10/5: 834- 840.

[26]. Mair, P.(2005) 'Popular democracy and the European Union polity', European Governance Papers (EUROGOV) no.C-05-03.

[27]. March, J.G. and Olsen, J.P. (1995)Democratic Governance, New York: The Free Press.

[28]. Mehde, V.(2003) 'Responsibility and accountability in the European Commission', Common Market Law Review40: 423-442.

[29]. Meijer, A. and Schillemans, T.(2007) 'Fictitional citizens and real effects: accountability to citizens in competitive 
markets', Administration and Society, (forthcoming).

[30]. Mulgan, R.(2000) “'Accountability”: an ever expanding concept?’ Public Administration,78: 555.

[31]. Mulgan, R.(2003)Holding Power to Account: Accountability in Modern Democracies, Basingstoke: Palgrave.

[32]. O’Donnell, G.(1999) 'Horizontal Accountability in New Democracies', in A. Schedler, L. Diamond and M.F. Plattner (eds.)The Self-Restraining State: Power and Accountability in New Democracies, London: Lynne Rienner Publishers, pp.29-51.

[33]. Pollitt, C.(2003)The Essential Public Manager, London: Open University Press/McGraw-Hill Przeworski, A., Stokes, S.C. and Manin, B. (eds.) (1999) Democracy, Accountability, and Representation, Cambridge: Cambridge University Press.

[34]. Scharpf, F.(1999)Governing Europe: Efficient and Democratic? Oxford: Oxford University Press.

[35]. Schmitter, P.(2000)How to Democratize the European Union And Why Bother?, Lanham: Rowman and Littlefield.

[36]. Scott, C.(2000) 'Accountability in the regulatory state', Journal of Law and Society, 27(1): 38-60.

[37]. Ziller, J. (2001) 'European models of government: towards a patchwork with missing pieces', Parliamentary Affairs, 54: 102-119. 